\title{
Evaluation of the performance of a hydraulic barrier by the Null space Monte Carlo method
}

\section{Valutazione delle prestazioni di una barriera idraulica tramite applicazione del metodo Null space Monte Carlo}

\author{
G. Formentin, J. Terrenghi, M. Vitiello, A. Francioli
}

\begin{abstract}
Riassunto: Una perdita di idrocarburi ha contaminato l'acquifero superficiale sottostante un'area urbanizzata del Nord Italia. La diffusione della contaminazione è stata evitata realizzando una barriera idraulica, posizionata a valle della sorgente, per intercettare sia il prodotto in fase libera che quello disciolto in falda.

È stato quindi predisposto un modello numerico per valutare l'efficienza dell'attuale barriera e per progettare una nuova configurazione finalizzata al contenimento del pennacchio di contaminazione.

Il modello preliminare è stato calibrato variando la conducibilità idraulica (rappresentata tramite pilot point), la ricarica superficiale e le condizioni al contorno di carico costante. Come osservazioni è stato utilizzato il livello di falda misurato in $\mathrm{n}$. 41 piezometri.

L'incertezza legata alla calibrazione ha permesso di identificare 283 differenti set di parametri che permettono di replicare i carichi idraulici osservati con un errore medio assoluto di 10 $\mathrm{cm}$. Questi set di dati, generati con il metodo Null space Monte Carlo, sono stati inseriti nel modello di flusso per simulare la dispersione della contaminazione tramite il tracciamento delle particelle.
\end{abstract}

Keywords: MODFLOW, MODPATH, PEST, Null space Monte Carlo, bydraulic barrier.

Parole chiave: MODFLOW, MODPATH, PEST, Null space Monte Carlo, barriera idraulica.

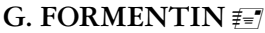

Tethys S.r.l

Viale Lombardia 11, 20131 Milano, Italia

giovanni.formentin@tethys.srl

\section{J. TERRENGHI, A. FRANCIOLI}

Soil \& Groundwater, HPC Italia Srl

Via Francesco Ferrucci 17/A, 20145 Milano, Italia

\section{VITIELLO}

Tethys S.r.1

Viale Lombardia 11, 20131 Milano, Italia

Ricevuto/Received: 24 October 2019-Accettato/Accepted: 19 December 2019 Pubblicato online/Published online: 20 December 2019

This is an open access article under the CC BY-NC-ND license: http://creativecommons.org/licenses/by-nc-nd/4.0/

CC Associazione Acque Sotterranee 2019
Un passo successivo è stata l'eliminazione delle simulazioni in cui le traiettorie delle particelle distano meno di $5 \mathrm{~m}$ da piezometri che, dalle analisi chimiche, risultano non contaminati. Dall'analisi dei percorsi delle particelle dei 187 modelli rimanenti, risulta che la barriera cattura complessivamente 1'89\% delle particelle generate. Inoltre, nel $74 \%$ delle realizzazioni, almeno una particella non viene catturata dalla barriera, con una media e una mediana di $n .7$ particelle.

Le traiettorie identificano due percorsi principali di diffusione della contaminazione: uno di questi è confermato dai piezometri, l'altro necessita l'installazione di piezometri per verificare la qualità della falda. In questo modo, si verificherebbe la validità delle simulazioni stocastiche svolte insieme alla necessità di migliorare le prestazioni della barriera idraulica.

Abstract: A gasoline leak caused the contamination of a shallow alluvial aquifer in an urbanized area in Northern Italy.

A rapid intervention was conceived to stop the spreading of contamination: a bydraulic barrier has been placed downstream of the source to collect both the floating oil and the contaminated groundwater.

A numerical model has been built to assess the performance of the existing barrier, and to design a new configuration of the bydraulic barrier aimed at stopping the hydrocarbon plume already dispersed downstream. A preliminary model was built and calibrated against groundwater levels measured in 41 monitoring wells. Hydraulic conductivities in pilot points, recharge zones and constant head BCs were calibrated.

The non-uniqueness of the calibrated parameters led to identify 283 alternative parameter sets, all able to represent the observed heads within an absolute average error of $10 \mathrm{~cm}$. These sets, generated with the Null space Monte Carlo method, served to build 283 models, used to simulate the dispersion of solved contamination through forward particle tracking. A further step was the censoring of all simulations resulting in particle paths at a distance closer than 5 meters from monitoring wells where contamination was never found since the spilled occurred. Analysis was performed of the particle paths generated with the 187 models that were retained. Overall, the barrier captures $89 \%$ of all particles. Moreover, in $74 \%$ of all realizations, at least a particle escapes, with a mean and median of 7 particles in each realization where it happens.

Two main contamination paths are identified: while one is confirmed by the monitoring wells already present, another one would require the placement of new wells to assess the actual presence of contamination. Thus, the validity of the stochastic simulation would be assessed together with the need to improve the performance of the hydraulic barrier. 


\section{Introduction}

The present work describes a real case contamination located in an urbanized area in Northern Italy that is polluted by hydrocarbons.

An emergency Pump\&Treat system was activated to intercept the contamination plume. Remediation is completed by extraction of contaminated gases with a Soil Venting system.

The hydraulic barrier is composed of a first line made by three wells (W1, W2 and W3) and three more wells downgradient (W4, W5 and W6). The barrier and the monitoring network are displayed in Figure 1. The total flow rate extracted by the six wells is $5.3 \mathrm{l} / \mathrm{s}$.

A numerical model has been built using MODFLOW-2000 (Harbaugh et al. 2000) to assess the performance of the existing barrier, and to design a new configuration of the hydraulic barrier aimed at stopping the hydrocarbon plume already dispersed downstream.

A preliminary model was built and calibrated against groundwater levels measured in 41 monitoring wells. Hydraulic conductivities in pilot points, recharge zones and constant head BCs were calibrated.

The aim of the study is to evaluate the effectiveness of the hydraulic barrier considering the inherent uncertainty of the calibrated parameters.

The non-uniqueness of the determination of quantities tied to groundwater flow affects, with different degrees, all the realcase situations where the knowledge of the hydrogeological setting is affected by uncertainty. This uncertainty is then passed on to the predictions of interest. Therefore, the uncertainty of each model prediction is characterized by a probability density function with a mean, which is the approximation to the prediction of minimum error variance, and a standard deviation that provides the uncertainty of the model prediction (Herckenrath et al. 2011).
The available methods for quantifying uncertainty in predictions by use of a calibrated model (Tonkin and Doherty 2009), can be linear (i.e. implying a linear relationship between parameters and predictions, which rarely holds in real cases (Moore and Doherty 2005) or nonlinear, such as Monte Carlo methods (e.g., Christensen and Cooley 1996; Carrera et al. 2005; Guadagnini and Neuman 1998; Harvey and Gorelick 1995). The Null space Monte Carlo method (Tonkin and Doherty 2009) allows to produce a multitude of calibrationconstrained stochastic parameter fields, by the use of which the variability in the predictions of interest, deriving from lack of information on the model parameters, can be estimated.

In this study, the PEST code (Doherty 2015) was used to calibrate the model and generate 283 alternative models using the Null space Monte Carlo method.

A second step was the selection of only those realizations that respected measured concentrations. Particle tracking was used as a tool to represent solute transport, similarly to what has been performed in other studies (e.g. Alberti et al. 2018, Moeck et al. 2019). In this case, measured concentrations in monitoring wells were compared with contaminant paths calculated by the code MODPATH (Pollock 2012). The particle paths resulting from all the remaining simulations were collected and analysed together allowing to calculate different statistics informative of the hydraulic barrier performance.

\section{Data and Methods \\ Hydrogeology of the area}

The hydrogeology of the area comprising the study site (the location of which cannot be disclosed for confidentiality reasons) is known from the logs of several monitoring and drinking wells reaching depths of over 100 meters. A succession of overlying gravel and sand aquifers is found,

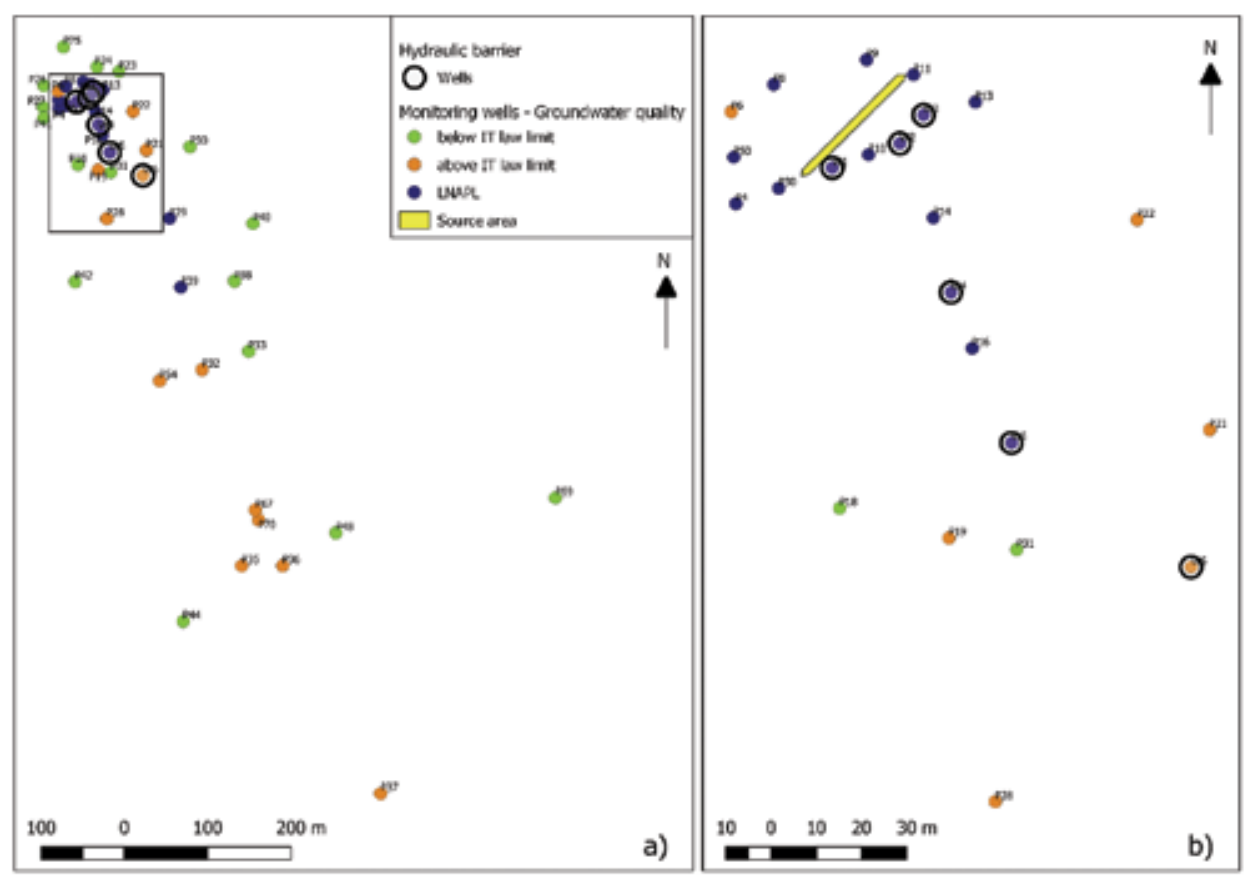

Fig. 1 - Area of interest (a) and detail view of the spill area and of the hydraulic barrier (b).

Fig. 1 - Area di studio (a) e dettaglio dell'area sorgente e della barriera idraulica (b). 
separated by silt and clay levels.

The contamination was found only in the upper unconfined aquifer. This aquifer consists of a 20 -m-thick succession of coarse lithology, mainly gravel with a sandy matrix, overlaying a clayey-silty aquitard. This aquitard has a thickness of about $0.5 \mathrm{~m}$ to $9 \mathrm{~m}$ and it is assumed to be continuous in the modelled area (three boreholes in the modelled area reached it but did not cross it). The underlying succession consists of sands and sandy gravels layers passing to pebbles with interposed clayey levels.

The top aquifer is unconfined and groundwater flows from $\mathrm{NO}$ to SE. The water-table depth in the study area ranges between 5-10 m (Northern part) and 0-5 m (Southern part) from the ground surface. Therefore, groundwater level is affected by seasonal fluctuations showing minimum and maximum levels in April and August, respectively. The maximum level is linked to irrigation recharge. The water table elevation, measured in April 2017 ranges from about $138 \mathrm{~m}$ a.s.l. and $134.2 \mathrm{~m}$ a.s.l. The medium groundwater gradient is $0.25 \%$.

\section{Numerical model of groundwater flow and particle tracking}

A numerical groundwater flow model was developed with the finite-difference code MODFLOW-2000 (Harbaugh et al. 2000). The contamination source is centred in the model domain, which is discretized by means of a $10 \mathrm{~m} \times 10 \mathrm{~m}$ cell grid. The model is made up of a total of 288 rows and 200 columns. Therefore, the grid dimension is $2880 \mathrm{~m} \mathrm{x} 2000$ $\mathrm{m}$. Vertically, the sandy-gravel portion $(20 \mathrm{~m})$ of the aquifer, where field evidence of the contamination was found, has been split into two layers with the same thickness. The layers have been set with the same initial hydraulic conductivity $(\mathrm{K})$ distribution. This parameter has then been included in the calibration set, as specified in the following section.

The boundary conditions have been assigned as follow:

- Constant head: upgradient and downgradient the domain;

- No flow: lateral and base of the domain;

- Specified flow: used to simulate wells of the hydraulic barrier and the surficial recharge.

Constant head values have been applied according to the water-table elevation interpolated from field data collected in April 2017, and then added to the calibration parameter set.

Recharge has been applied by distinguishing natural and urbanised areas. Recharge in natural areas sums the contributions of precipitation and irrigation. Recharge in urbanized areas simulates the losses from the water supply and sewer networks. Initial values of $8 \times 10-9 \mathrm{~m} / \mathrm{s}$ and $2 \times 10-9 \mathrm{~m} / \mathrm{s}$ have been attributed to natural and urbanised areas respectively, based on an estimate of potential evapotranspiration in natural areas using the PenmanMonteith method (Allen et al. 2005); recharge has then been added with zones of constant values to the parameter set subjected to calibration. Interpolated groundwater levels from measurements taken in different periods in the study area show flow directions that do not substantially vary throughout the year. Being flow directions the predictions of interest (because they determine advective transport), it is therefore assumed that they are not sensitive to the boundary conditions.

\section{Calibration, validation and null space Monte Carlo Calibration}

The model was calibrated in steady-state conditions with the code PEST (Doherty 2015). Hydraulic conductivity of the aquifer, recharge and the constant heads were subjected to calibration. $\mathrm{K}$ was calibrated through the pilot points method. Each point was characterized by a starting value and a reasonable range of hydraulic conductivity. PEST estimates and interpolates the values, then it iteratively runs the model with the new K field. Pilot point were set with two regular grids: one external that covers the entire domain with spacing of $250 \mathrm{~m}$, whereas the second innermost covers the contaminated area with spacing of $35 \mathrm{~m}$.

Total number of estimated parameters is 308 subdivided as follow: 304 pilot points for hydraulic conductivity, two constant head values and two recharge zones. Regularization was also applied with the aim to attain a solution of minimum error variance to the calibration inverse problem (Doherty et al. 2010). In particular, Tikhonov regularization (Tikhonov et al. 1977) was applied by supplementing the calibration dataset with observations in the form of equations linking the $\mathrm{K}$ values of neighbouring pilot points. PEST has thus been informed that the hydraulic conductivity was expected to be uniform within the whole of the model area. Consequently, PEST would only introduce heterogeneity in the $\mathrm{K}$ field in the measure that is strictly necessary to attain a satisfactory fit to observed heads.

The calibration process is based on the water levels measured in April 2017 in 41 monitoring wells inside the study area.

The calibration statistics are reported in Tab. 1. The maximum absolute residual is equal to $9 \mathrm{~cm}$. The root mean square error is $0.03 \mathrm{~m} 2$. Residuals appear uniformly distributed around the value of $0 \mathrm{~m}$ and the simulation of the water table elevation is realistically reproduced (Fig. 2). Although differences are visible between the observed and simulated groundwater head contours in the North-East and South-West parts of the model, they can be attributed to distortions in the kriged interpolation that is not directly informed by measured heads in those parts of the domain.

\section{Validation}

Water table elevation values of May 2017, measured in 39 monitoring wells, were used to validate the model. Because a general increase of 0.3 to $0.5 \mathrm{~m}$ is observed in groundwater level compared to April 2017, the constant head values and recharge were subjected to recalibration with PEST, while the hydraulic conductivity field was kept equal to the one estimated in calibration. PEST estimated an increase in recharge in natural areas (from $63 \mathrm{~mm} / \mathrm{y}$ to $315 \mathrm{~mm} / \mathrm{y}$ ) and a $0.3 \mathrm{~m}$ increase in the downgradient constant head value. Both 


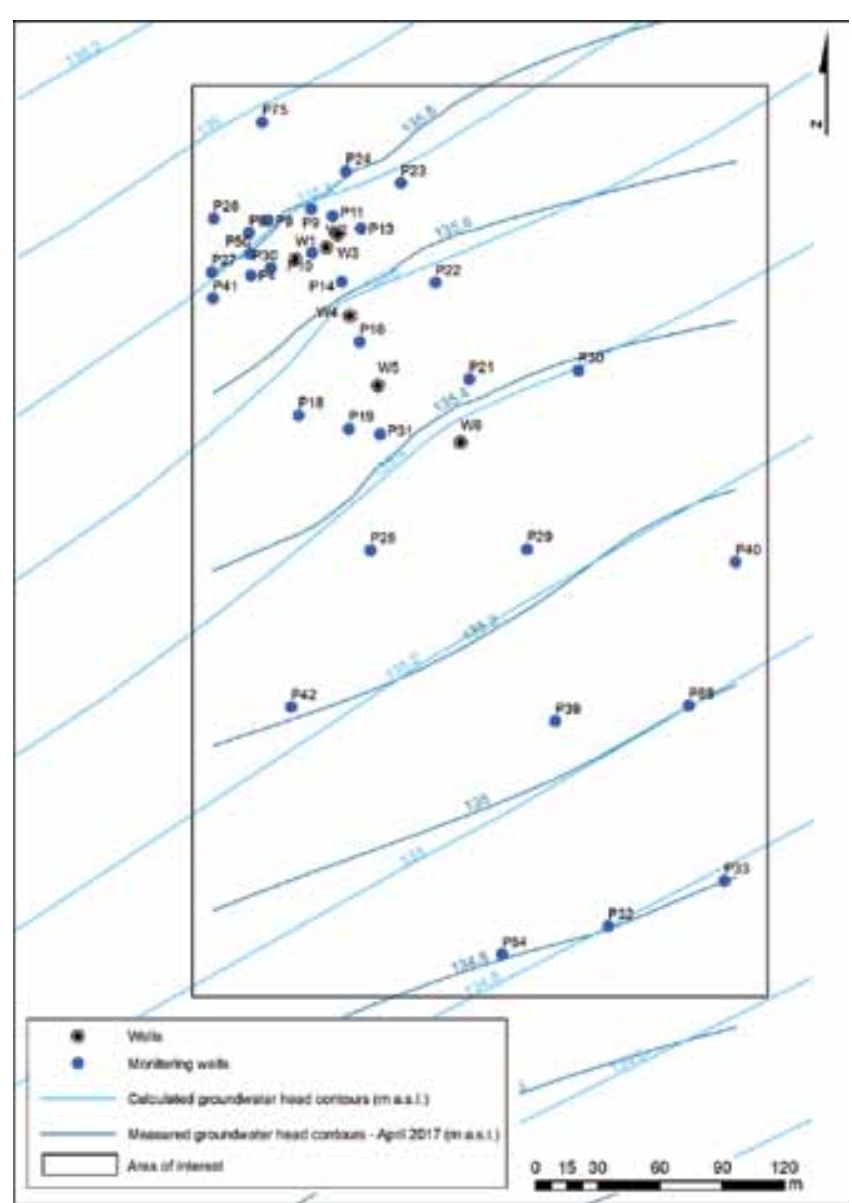

Fig. 2 - Simulated and interpolated water table map based on April 2017 measurements. The black box identifies the area of interest.

Fig. 2 - Piezometrie simulata e interpolata sulla base di misure di aprile 2017. Il rettangolo nero identifica l'area di interesse.

recharge in urban areas and the upgradient constant head value were not modified. These modifications do not alter groundwater directions, that remain very similar to those simulated in the scenario of April 2017.

The absolute residual mean increases from $0.02 \mathrm{~m}$ to 0.07 $\mathrm{m}$. The maximum absolute residual increases to $0.25 \mathrm{~m}$. Overall, the validation statistics (see Tab. 1) are considered acceptable.

Tab. 1 - Calibration and validation statistics.

Tab. 1 - Statistiche di calibrazione e validazione.

\begin{tabular}{|lc|c|}
\cline { 2 - 3 } \multicolumn{1}{c|}{} & Calibration & Validation \\
\hline Date & April 2017 & May 2017 \\
\hline Observation number & 41 & 39 \\
\hline Residual mean & $0.00 \mathrm{~m}$ & $0.00 \mathrm{~m}$ \\
\hline Absolute residual mean & $0.02 \mathrm{~m}$ & $0.07 \mathrm{~m}$ \\
\hline Root mean square (RMS) & $0.03 \mathrm{~m}$ & $0.10 \mathrm{~m}$ \\
\hline Minimum residual & $-0.09 \mathrm{~m}$ & $-0.22 \mathrm{~m}$ \\
\hline Maximum residual & $+0.06 \mathrm{~m}$ & $+0.25 \mathrm{~m}$ \\
\hline Observation range & $4.16 \mathrm{~m}$ & $3.19 \mathrm{~m}$ \\
\hline RMS / Observation range & $0.7 \%$ & $3.0 \%$ \\
\hline
\end{tabular}

\section{Particle tracking}

The reference scenario of April 2017 represents the average directions of groundwater flow (which are the basis for the predictions of interest in the present case), as shown by the interpolation of groundwater levels measured in different periods. Therefore, this scenario was used for the forward particle tracking simulations by the code MODPATH. Accordingly, a line of particles was located along the contamination source, oriented perpendicular to the main flow direction. Particles tracks follow the groundwater direction according to advective transport paths. Results show that all the particles are captured by the hydraulic barrier.

Although this method only accounts for the advective process, it is much easier than the implementation of a numerical transport model, for which additional information such as dispersive parameters (unavailable in the present case), should be collected. Moreover, it is assumed that the dispersion determined by uncertainty in model parameters supplies for the combined effect of mechanical dispersion and diffusion, that are not represented in MODPATH. In other words, building a full transport model in a real case site where information is not sufficient to constrain the parameters that control solute transport is deemed to be a complex exercise that, although representing all transport mechanisms in a physically coherent fashion, gives little more than the false impression of generating reliable results, when what remains understated in this process is the predictive uncertainty resulting from the uncertainty tied to every model parameter. In such cases, explicitly representing the uncertainty in model parameters by a Monte Carlo method determines a spread in contaminant concentrations that satisfactorily approximates, without the burden of building a full transport model and the need to estimate additional model parameters, the effect of the mechanisms of contaminant dispersion not accounted for in an advective-only model (Formentin et al. 2018).

The Null space Monte Carlo (NSMC) method used in this case, allows to produce a multitude of calibration-constrained stochastic parameter fields, by use of which the variability in the predictions of interest, deriving from lack of information on the model parameters, can be estimated. NSMC has been applied by generating 333 alternative models. A threshold of $10 \mathrm{~cm}$ for absolute residual mean, with April 2017 field measures as reference data, has been considered to define reliable models: 50 models were rejected and 283 models were considered suitable for forward particle tracking analysis through MODPATH code. Examples of the different hydraulic conductivity fields that were generated, all calibrating the model against observations, are displayed in Fig. 3. The effect of Tikhonov regularization is evident here in the fact that the range of $\mathrm{K}$ values is narrow, as expected in a homogeneous aquifer: PEST only added as much heterogeneity as strictly required to satisfactorily represent the observed heads.

A number of 50 particles were released from the spill area to represent the dispersion of solute hydrocarbons within the shallow aquifer. The paths of a total number of 14150 particles were collected and examined in a GIS. Also concentrations 
of the contaminants released by the spill were analysed: all the monitoring wells in the area were divided into three categories based on water samples collected during the whole monitoring period:

1. the wells where LNAPL was found;

2. the wells that showed at least one exceedance of the Italian law limits (D.Lgs. 152/06) for any contaminant;

3. the wells in which collected groundwater had always contained contaminants below the Italian law limits.

The realizations in which at least a particle path was closer than 5 meters to a monitoring well pertaining to the third category (monitoring wells with contamination below the law limits) were excluded from the pool, as the directions of solute contamination were not confirmed by measured concentrations. The ensemble of censored realisations was analysed to assess the barrier performance.

The analysis was performed of the particle paths generated with the 187 models that were retained.
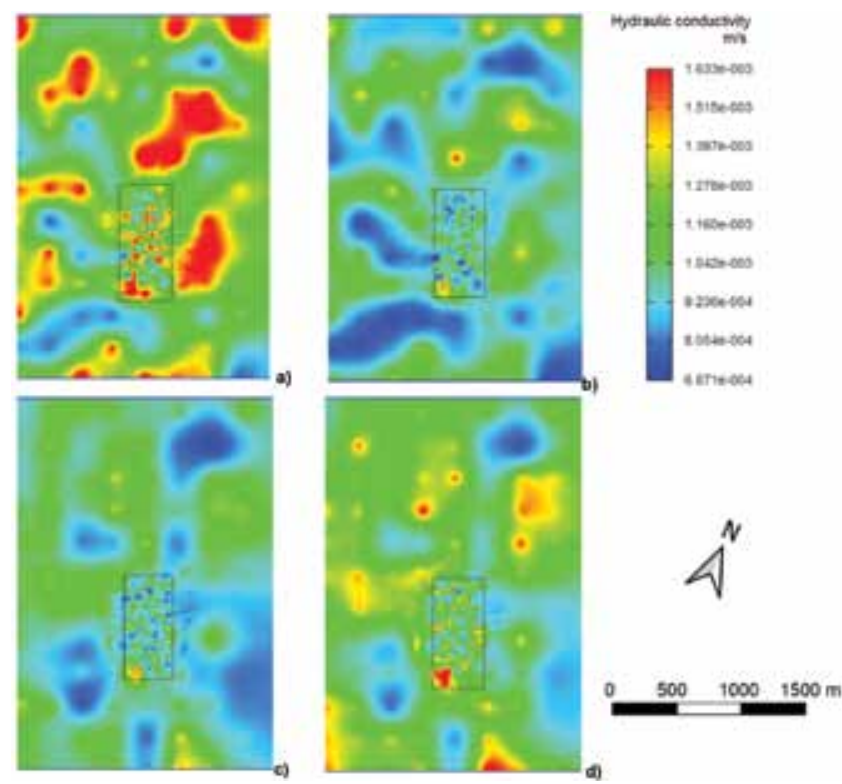

Fig. 3 - Four realisations of hydraulic conductivity fields over the entire model domain. The black box identifies the area of interest. The higher density of pilot points in the central area determines an increased granularity in the distribution of conductivity therein.

Fig. 3 - Quattro realizzazioni di campi di conducibilità idraulica sull'intero dominio di modellazione. Il rettangolo nero identifica l'area di interesse. La maggiore densità di pilot points nell'area centrale determina una maggiore granularità nella distribuzione di conducibilità idraulica.

\section{Results and discussion}

The ending position of every path was counted to assess the number of total particles captured by each barrier well. Statistics are shown in Tab. 2.

Overall, the barrier captures $89 \%$ of all particles. Moreover, in $74 \%$ of all realizations, at least a particle escapes, with a mean and median of 7 particles in each realization where it happens.

The first line of wells (W1, W2 and W3) captures over $67 \%$ of all generated particles (thus taking into account also those particles that escape all wells). $17 \%$ of the remaining particles are captured by W4, while W5 and W6 together capture almost $5 \%$ of all particles. The ratio of number of captured particles to extracted flow rate gives an indication of the efficiency of contaminant extraction by each well. Wells W1, W2 and W4 have the highest value, at around 3000 particles per unit of flow rate. Extraction by W6 yields only 81 particles per unit of flow rate. Comparison of these values to the actual contaminant concentration of extracted groundwater - or to the total mass extracted by each well - would be required to confirm the results and will be performed in a following study.

A number of 1443 particles (11\% of the total) escape all wells of the hydraulic barrier, flowing through different paths towards the downgradient boundary conditions (Fig. 4). By counting the total number of particles crossing each model cell (Fig. 5), two main paths emerge. One of these showed, in past monitoring campaigns, the presence of LNAPL; this proves as a confirmation of the simulation result. Another path runs parallel to the previous, but no monitoring well lies along it. Therefore, installation of one or more monitoring wells along this path would be required to confirm the current presence of pollution that escapes the hydraulic barrier. If this is confirmed by groundwater analyses, the performance of the hydraulic barrier would need to be improved, e.g. increasing the pumping rates in one or more wells.

As shown in Fig. 4b, two monitoring wells (P22 and P28) that registered concentrations of total hydrocarbons above the law limit are not reached by any particle. This may be due to different reasons, with the most likely being (1) the imprecise delimitation of the known source (or of the extent reached by LNAPL) and (2) variations in groundwater direction that the model does not account for. The presence of other sources

Tab. 2 - Statistics of captured particles by the hydraulic barrier wells.

Tab. 2 - Statistiche di cattura delle particelle da parte dei pozzi della barriera idraulica.

\begin{tabular}{|l|c|c|c|c|}
\hline Well & Captured particles & $\begin{array}{c}\text { Captured over total } \\
\text { generated particles }\end{array}$ & $\begin{array}{c}\text { Captured over total } \\
\text { captured particles }\end{array}$ & $\begin{array}{c}\text { Flow rate } \\
(\mathbf{l} / \mathbf{s})\end{array}$ \\
\hline W1 & 3348 & $24.6 \%$ & $27.5 \%$ & 1.11 \\
\hline W2 & 3844 & $28.2 \%$ & $31.5 \%$ & 1.11 \\
\hline W3 & 1993 & $14.6 \%$ & $16.3 \%$ & 1.11 \\
\hline W4 & 2347 & $17.2 \%$ & $19.3 \%$ & 0.833 \\
\hline W5 & 613 & $4.5 \%$ & $5.0 \%$ & 0.556 \\
\hline W6 & 45 & $0.3 \%$ & $0.4 \%$ & 116 \\
\hline Total & 12190 & $89.4 \%$ & $100.0 \%$ & 518 \\
\hline
\end{tabular}


of hydrocarbons, not unlikely in a densely urbanized area, is another potential explanation.

\section{Conclusions}

Numerical models are built in almost every case where a hydraulic barrier needs to be installed in contaminated sites. They are often built under deterministic assumptions, i.e. calibration provides the set of parameters that minimize a statistic of the difference between observation and their model counterparts.
This study shows that uncertainty in parameters, which is always present due to the impossibility to know perfectly the hydrogeological setting, adds to other sources of error (e.g. measurement errors, structural noise, simplifications) that could potentially lead to designing interventions that do not guarantee the required performance.

Stochastic analysis, performed by the NSMC method, has been applied to enhance the knowledge about the variability in model predictions.

A MODFLOW model has been calibrated and validated
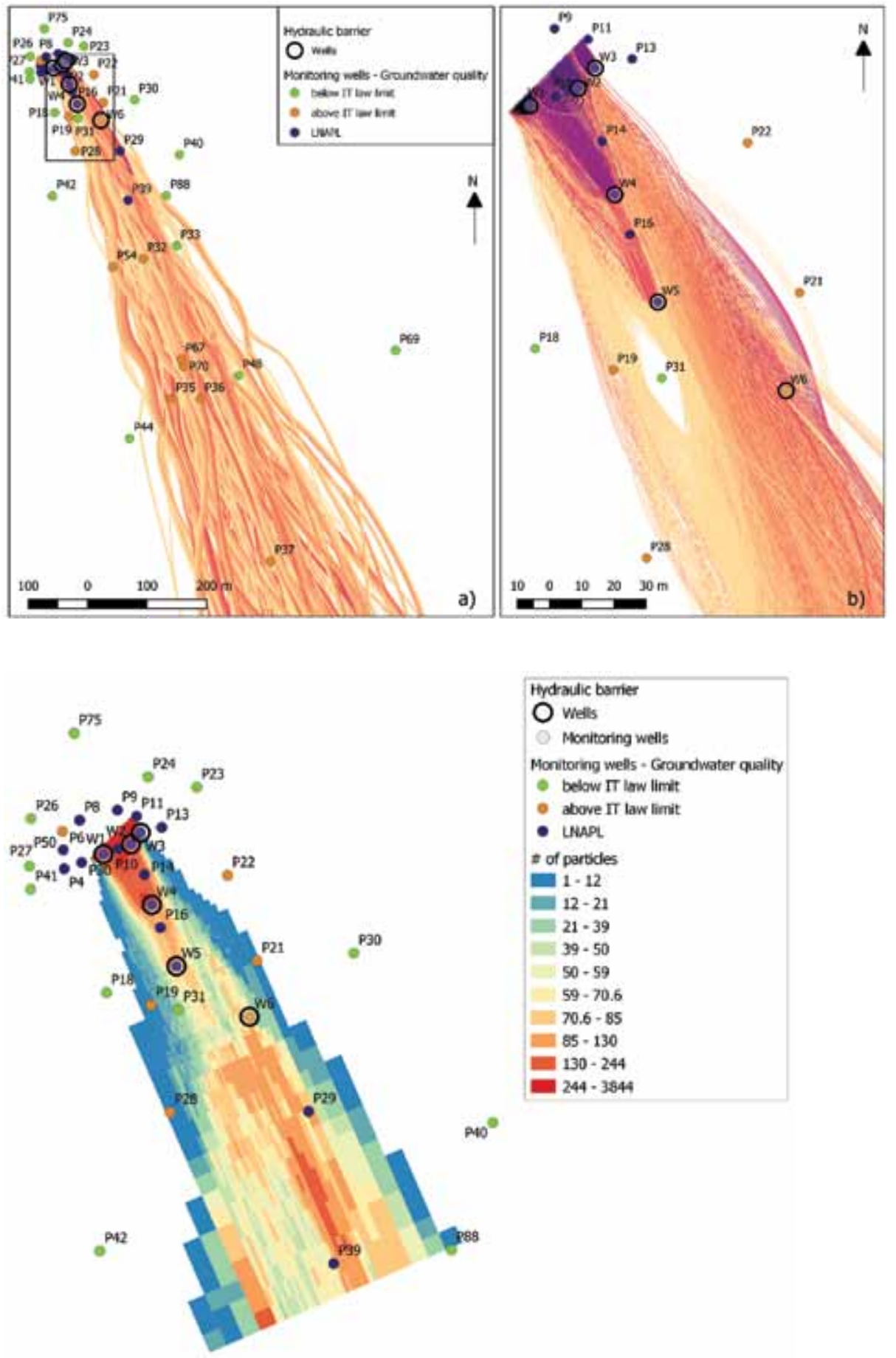

Fig. 4 -Particle paths calculated for all realizations. The path colours represent the distance to the closest monitoring well with contaminant concentrations below the law limit. (a) area of interest (a) and (b) detail view of the spill area and of the bydraulic barrier.

Fig. 4 - Percorsi delle particelle calcolati per tutte le realizzazioni. I colori delle traiettorie rappresentano la distanza dal più vicino piezometro nel quale non sono state misurate eccedenze dei limiti di legge. (a) area di studio e (b) dettaglio dell'area sorgente e della barriera idraulica.
Fig. 5 - Count of particles in each model cell. The dark colours represent the cells with the higher number of particles passing through.

Fig. 5 - Conteggio delle particelle in ogni cella del modello. I colori più scuri rappresentano le celle con il numero maggiore di passaggi di particelle. 
with head measurements. Subsequently, 283 alternative models have been built with the NSMC method. MODPATH has been applied to these models to simulate contaminant paths, under the assumption that dispersion of particles due to variability in flow parameters would compensate for mechanic dispersion and diffusion, that are not represented in the code.

Those models generating paths that flow close to monitoring wells with absent contamination (measured concentrations were below the Italian law limit) were excluded from the pool.

Results of the remaining models were analysed in a GIS, identifying the overall hydraulic barrier effectiveness together with two main contaminant paths that are not currently captured by the wells. One path is confirmed by concentration data; while the other requires the installation of monitoring wells for groundwater collection and analysis. Whether the contamination path is confirmed, an improvement of the barrier performance would be required, e.g. increasing the pumping rates of one or more wells. Thus, the validity of the stochastic simulation would also be assessed, potentially casting more doubts on the validity of deterministic models in providing reliable results when parameters are highly uncertain, such as in most real-world groundwater cases.

\section{REFERENCES}

Alberti L, Colombo L, Formentin G (2018) Null-space Monte Carlo particle tracking to assess groundwater PCE (Tetrachloroethene) diffuse pollution in north-eastern Milan functional urban area. Sci Total Environ 621:326-339. doi:10.1016/j.scitotenv.2017.11.253

Allen RG, Walter IA, Elliott R, Howell TA, Itenfisu D, Jensen, ME (2005) The ASCE standardized reference evapotranspiration equation, Idaho, Task Committee on Standardization of Reference Evapotranspiration.

Carrera J, Alcolea A, Medina A, Hidalgo J, Slooten LJ (2005) Inverse problem in hydrogeology. Hydrogeol. J. doi:10.1007/s10040-0040404-7

Christensen S, Cooley RL (1996) Simultaneous confidence intervals for a steady-state leaky aquifer groundwater flow model. Calibration and Reliability in Groundwater Modelling, p. 561-569.

Doherty JE, Hunt R (2010) Approaches to highly parameterized inversion - A quide to using PEST for groundwater-model calibration. U.S. Geological Survey Scientific Investigations Report 2010-5169, $59 \mathrm{p}$.

Doherty JE (2015) Calibration and Uncertainty Analysis for Complex Environmental Models. Watermark Numerical Computing, Brisbane, Australia. ISBN: 978-0-9943786-0-6.

Formentin G, Rigamonti DS, Francioli A, Terrenghi J, Giambelli G, Bonfanti M (2018) Modello stocastico per il barrieramento idraulico basato su metodi sostenibili per il calcolo dei parametri idrodinamici "A stochastic model for groundwater containment based on sustainable methods to estimate hydrodinamic parameters". Rend. Online Soc. Geol. It., Vol. 48 (2019), pp. 41-46. doi:10.3301/ROL.2019.36

Guadagnini A, Neuman SP (1998) Deterministic solution of stochastic groundwater flow equations by nonlocal finite elements. Comput. Methods Contam. Remediat. Water Resour. 12, 347-354.

Harbaugh AW, Banta ER, Hill MC, McDonald MG (2000) MODFLOW-2000, the U.S. Geological Survey modular ground-water model - User guide to modularization concepts and the GroundWater Flow Process: U.S. Geological Survey Open-File Report 0092, $121 \mathrm{p}$.

Harvey CF, Gorelick SM (1995) Temporal moment-generating equations - modelling transport and mass transfer in heterogeneous aquifers. Water Resour. Res. 31,1895-1911.

Herckenrath D, Langevin CD, Doherty J (2011) Predictive uncertainty analysis of a saltwater intrusion model using null-space Monte Carlo. Water Resour. Res. 47. doi:10.1029/2010WR009342

Moeck C, Molson JW, Schirmer M (2019) Pathline Density Distributions in a Null-Space Monte Carlo Approach to Assess Groundwater Pathways. Ground Water. doi:10.1111/gwat.12900

Moore C, Doherty JE (2005) Role of the calibration process in reducing model predictive error. Water Resour. Res. 41. doi:10.1029/2004WR003501

Pollock DW (2012) User Guide for MODPATH Version 6-A ParticleTracking Model for MODFLOW: U.S. Geological Survey Techniques and Methods 6-A41, $58 \mathrm{p}$.

Tikhonov AN, Arsenin VY (1977) Solution of Ill-Posed Problems. VH Winston and Sons, Washington, D.C.

Tonkin M, Doherty JE (2009) Calibration-constrained Monte Carlo analysis of highly parameterized models using subspace techniques. Water Resour. Res. 45. doi:10.1029/2007WR006678 